\title{
Zooplankton in a marine bay. III. Evidence for influence of vertebrate predation on distributions of two common copepods
}

\author{
W. J. Kimmerer*, A. D. McKinnon** \\ Department of Zoology, University of Melbourne, Parkville, Victoria 3052, Australia
}

\begin{abstract}
The copepod Acartia tranteri is numerically dominant in Westernport Bay, Australia, while Paracalanus indicus is the most abundant species immediately outside the bay. We investigated several aspects of the ecology of these 2 species to attempt to explain why $P$. indicus was excluded from the bay. Four hypotheses were proposed to explain the distributions on the basis of: (1) feeding; (2) growth and reproduction; (3) predation by $A$. tranteri; and (4) differential predation by other invertebrates or by fish. Experimental and field evidence was used to reject Hypotheses 1 to 3. Invertebrate predation showed no apparent selectivity, but predation by small, common planktivorous fish was selective. In experiments of 2 designs and with 2 species of fish, $P$. indicus was preyed upon about twice as much as $A$. tranteri, at least partly because of difterences in escape response. A field experiment confirmed that $P$. indicus was consumed about twice as fast as A. tranteri, and that the mortality rate was sufficient to produce the observed effect. We hypothesize that visual predation is more important in shallow than in deep waters, resulting in the exclusion of species vulnerable to visual predators. Since the observed distribution patterns are common in temperate marine bays and estuaries, the proposed mechanism. may also be general.
\end{abstract}

\section{INTRODUCTION}

One of the principal goals of biological oceanography is to understand the distribution, abundance, and diversity of plankton. Interest in diversity patterns in oceanic plankton has most often focused on the elevated diversity in gyre waters (McGowan 1974). Here we consider the reduced diversity commonly observed in the plankton of bays and estuaries (Riley 1967, Miller 1983).

The physiological effects of reduced salinity can explain the low diversity in estuaries (Kinne 1967) but not in marine bays, where diversity can also be low (Landry 1978, Kimmerer \& McKinnon 1985). Alternative explanations for low diversity in marine bays include: thermal stress; high flushing rates from bays; behavior of zooplankton species that reduces transport into or out of bays; poor or variable food supply in bays; and selective predation in bays.

Diversity in bays can be reduced both by the

- Present address: BioSystems Analysis, Inc., Bldg 1065, Ft. Cronkhite, Sausalito, California 94965, USA

- Present address: Australian Institute of Marine Science, PMB No. 3, Townsville, Queensland, Australia increased absolute (and therefore relative) abundance of resident species and by the reduced absolute abundance of non-resident species (Kimmerer \& McKinnon 1987b). Of the mechanisms listed above, only thermal stress and predation would reduce the absolute abundance of non-resident species. High flushing or mixing rates can prevent the formation of resident populations of some or all species (Rogers 1940, Ketchum 1954, Barlow 1955), but without net advective flow a behavioral mechanism is required to reduce the absolute abundance of non-resident species. Zooplankton can exert some control over their horizontal position through the interaction of vertical movement with current shear, but this has not been observed to keep non-resident species out of bays (Kimmerer \& McKinnon $1987 \mathrm{c}$ ). Food concentrations in bays are normally higher than in adjacent neritic waters (Paffenhöfer \& Stearns 1988), so the species with the highest reproductive rate should become numerically dominant if mortality rates are equal, although other species would not be eliminated.

Predation within a bay could act to reduce diversity in 2 ways. First, if a numerical dominant also preys upon other species, then the absolute as well as relative 
abundance of the prey should decrease as the abundance of the dominant increases. Second, if speciesselective predators inhabit bays in sufficient abundance to affect the population dynamics of their prey, the species most heavily preyed upon will become less abundant than other species, all else being equal.

A large body of literature attests to the importance of predation in influencing species, sex, and size composition, abundance, morphology, and behavior of freshwater zooplankton (e.g. Brooks \& Dodson 1965, Maly 1970, Zaret \& Kerfoot 1975, Hall et al. 1976, O'Brien et al. 1976, Drenner \& McComas 1980, Warren et al. 1986). Much of this knowledge about effects of planktivory has been gained through comparisons of 2 or more sites, which is difficult in marine waters. Still, many of the mechanisms noted above have been observed in marine waters, including selection for size, visibility, or activity (Reeve 1966, Newbury 1972, Durbin \& Durbin 1975, Sullivan 1980, Lonsdale 1981, Checkley 1982, Peterson \& Ausubel 1984, Fancett \& Kimmerer 1985). Selection for species is relatively uncommon (for examples see Heron 1973, Greve 1981, Jenkins et al. 1984). Predators in marine and estuarine waters, particularly gelatinous predators, clearly can reduce the abundance of zooplankton prey (e.g. Durbin \& Durbin 1975, Reeve \& Baker 1975, Reeve \& Walter 1976, 1978, Huntley \& Hobson 1978, Landry 1978, Kremer 1979, Lonsdale 1981, Purcell 1981, Deason \& Smayda 1982, Cushing 1983, Alldredge 1984, Davis 1984, Feigenbaum \& Kelly 1984, Möller 1984, Frank 1986, Rassoulzadegan \& Sheldon 1986). Predation can also affect species composition or distribution through some form of selectivity (Ryther \& Sanders 1980, Lonsdale 1981, Fulton 1982, 1983, 1984a, b). In addition, predation appears to be the principal selective force behind at least some vertical migration in marine waters (Hobson \& Chess 1976, Robertson \& Howard 1978, Alldredge \& King 1980, Vuorinen et al, 1983, Fancett \& Kimmerer 1985), and can have a significant impact on prey population dynamics (Landry 1978).

The purpose of this paper is to present evidence testing hypotheses to explain the observed distributions of plankton in Westernport Bay, Australia, a shallow marine bay near Melbourne; the adjacent Port Phillip Bay was used for comparative purposes. The zooplankton of Westernport Bay is dominated numerically by a morph of Acartia tranteri, while that of Port Phillip Bay and adjacent shelf waters of Bass Strait is dominated by Paracalanus indicus and other morphs of A. tranteri (Kimmerer \& McKinnon 1985, 1987a, b, c). The morphs of A. tranteri appear to be at least 2 species, effectively distinguishable only by size (McKinnon 1988). In this paper we consider only $P$. indicus and the medium size class of $A$. tranteri.

Based on horizontal distributions and exchange rates, the Acartia population loses about $0.8 \% \mathrm{~d}^{-1}$ of its juveniles to mixing out of the bay (Kimmerer \& McKinnon $1987 \mathrm{~b}$ ); adults avoid that loss by vertical migration in synchrony with the tides (Kimmerer \& McKinnon $1987 \mathrm{C}$ ). Unlike other members of this genus (Landry 1978), A. tranteri does not migrate significantly on a diel cycle (Fancett \& Kimmerer 1985, Kimmerer \& McKinnon $1987 \mathrm{c}$ ). Paracalanus indicus suffers a net mortality of $3.2 \% \mathrm{~d}^{-1}$ in the bay that is offset by mixing in from the neritic population (Kimmerer \& McKinnon $1987 \mathrm{~b}$ ). In separate experiments, mortality rates of $A$. tranteri within the bay were found to average $6 \% \mathrm{~d}^{-1}$ for adults and $2 \% \mathrm{~d}^{-1}$ for copepodites, and to be higher in summer than in winter, at least for adults (Kimmerer \& McKinnon 1987a).

Several differences between the 2 bays may contribute to the differences in species composition: Westernport Bay is shallower, somewhat smaller, and more open to Bass Strait; tidal currents in Westernport Bay are stronger; the water in Westernport Bay is therefore more turbid and contains more detritus; and there are fewer planktonic predators in Westernport Bay (Kimmerer \& McKinnon 1985).

This paper focuses on the differences in the biology of Acartia tranteri and Paracalanus indicus that could produce the above differences in rates of gain or loss within the bay. Among the alternative explanations of the observed distributions listed above, that of thermal or salinity stress can be ruled out since the adjacent Port Phillip Bay has a similar temperature and salinity environment, but does not have a dominant population of A. tranteri. Position maintenance is of relatively minor importance because it applies only to adults of $A$. tranteri (Kimmerer \& McKinnon $1987 \mathrm{c}$ ). The residence time of Westernport Bay is about 2 mo (Kimmerer \& McKinnon 1987b), so flushing is clearly not an important cause of the differences. We therefore concentrated on those factors that could influence reproductive and mortality rates.

The observed patterns could be explained on the basis of differences between the 2 species in fecundity, development rate, or mortality. We set out a series of hypotheses related to these rates, as follows: (1) Acartia tranteri can maintain a higher feeding rate on phytoplankton than can Paracalanus indicus in water from Westernport Bay; (2) A. tranteri can maintain a higher reproductive, growth, or development rate than $P$. indicus in water from Westerport Bay, relative to their respective rates in water from Port Phillip Bay; (3) predation by $A$. tranteri on nauplii of $P$. indicus is sufficient to explain the difference in net mortality rates; and (4) predation by other species, either plankton or fish, is heavier on $P$. indicus than on $A$. tranteri, and sufficient to produce the observed differences.

The feeding hypothesis (1) would not provide an 
Table 1 Summary of experiments and field sampling conducted

\begin{tabular}{|c|c|c|}
\hline Hypothesis & Experiment & Objective \\
\hline 1 & Seston characterization & Size and taxonomic character of the seston \\
\hline 1 & Particle size selection & $\begin{array}{l}\text { Relative abilities of Paracalanus indicus and Acartia tranteri to collect food } \\
\text { particles of size range found in Westernport Bay }\end{array}$ \\
\hline 1 & Radiolabel feeding & $\begin{array}{l}\text { Abilities of the copepods to collect food in the background particulate } \\
\text { matter of Westernport Bay }\end{array}$ \\
\hline 2 & Egg production & $\begin{array}{l}\text { Egg production rate of each species in Westernport water relative to Port } \\
\text { Phillip water }\end{array}$ \\
\hline 2 & Growth rate & Same as above for growth rate of copepodites \\
\hline 3 & Acartia predation & Clearance rate of Acartia tranteri on Paracalanus indicus nauplii \\
\hline 4 & Invertebrate predation & Selectivity of predation by Catostylus and Tortanus on the 2 copepods \\
\hline 4 & Fish predation ( 2 prey) & Selectivity of predation by planktivorous fish on the 2 copepods \\
\hline 4 & Fish predation (1 prey) & Effect of prey escape response on predator success \\
\hline 4 & Simulated predation & Prey escape response \\
\hline 4 & Tidal creek sampling & Consumption rates and relative loss rates of the 2 copepods in a tidal creek \\
\hline 4 & Fish gut content analysis & Difference in predator selectivity on the copepod species \\
\hline
\end{tabular}

explanation for the observed pattern, but was included because to some extent feeding rate controls both fecundity and development rates, and because the food environment of the 2 bays was clearly different. Each of the remaining hypotheses as stated would be a necessary but insufficient condition for producing the observed patterns by the mechanism stated. Conversely, falsifying one or more of these hypotheses eliminates that factor as a possible cause. Our data are consistent only with Hypothesis 4, and suggest that predation by visually selective planktivores is the most important factor affecting the species composition of the zooplankton of Westernport Bay.

\section{METHODS}

Table 1 lists the experiments and field sampling efforts described here with the hypothesis being tested and the objective of each experiment.

Westernport Bay has been described in our previous reports (Kimmerer \& McKinnon 1985, 1987 a, b, c). Data to characterize the particulate matter of the 2 bays were obtained using water samples taken about twice monthly during 1984. Surface samples were collected in the eastern arm of Westernport Bay near Stn G (Kimmerer \& McKinnon 1987b) and at Stn K in Port Phillip Bay (Kimmerer \& McKinnon 1985). Analyses included total and $>10 \mu \mathrm{m}$ chlorophyll determined by in vitro fluorescence of filtered samples (GF/C) in acetone (Strickland \& Parsons 1972); and seston dry weight, determined by weighing tared filters on which seston from 100 to $500 \mathrm{ml}$ had been collected and dried at $60^{\circ} \mathrm{C}$ for $2 \mathrm{~d}$. In addition, on several occasions we

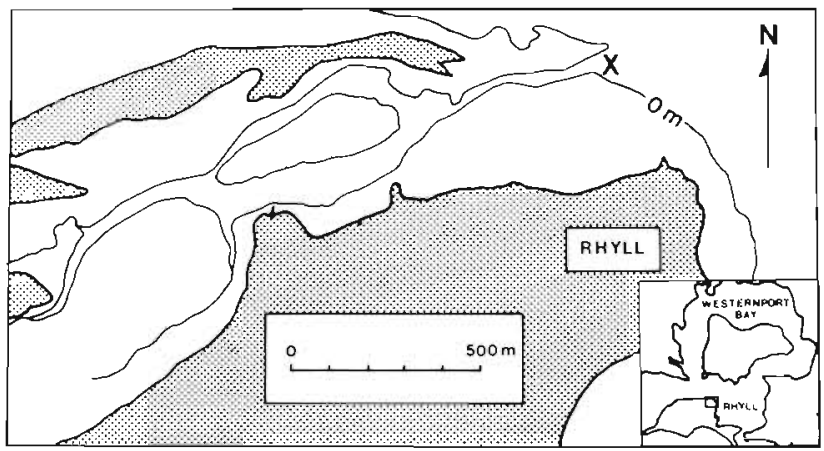

Fig. 1. Sampling site for tidal creek field experiment. X marks the sampling location, and the inset shows the location in Westernport Bay (see Kimmerer \& McKinnon 1987b)

collected whole water samples for identification of the dominant phytoplankton species. Samples were reduced to a small volume using a continuous flow centrifuge ( $R$. Wetherbee pers. comm.), and the concentrate was examined using phase contrast microscopy.

Except where noted, zooplankton samples were taken near Stn G in Westernport Bay (Kimmerer \& McKinnon 1987b; Fig. 1). Zooplankton for fish predation experiments were collected in a small inlet at the north end of the bay. Paracalanus indicus and water from Port Phillip Bay were taken at Stn K (Kimmerer \& McKinnon 1985). Zooplankton collections were made using 50 to $250 \mu \mathrm{m}$ mesh nets towed as gently as possible immediately below the surface. Plankton samples were diluted to 201 of surface seawater in insulated buckets for transport to the laboratory. Experiments were run in a constant temperature room at a 
temperature and light:dark cycle close to those in the bays. Containers used to handle or incubate animals were cleaned with strong detergent (Decon 90) and rinsed 3 times each with tap water, distilled water, and with ambient seawater just before use. Phytoplankton used in experiments were maintained in log-phase batch cultures under the same light and temperature regime as in the experiments.

Feeding experiments. In one series of experiments we determined the size ranges of particles consumed by the 2 species of copepod for comparison with ambient size distributions. Ten to 20 copepods were incubated in $250 \mathrm{ml}$ bottles for $24 \mathrm{~h}$ on a wheel rotating at $1 \mathrm{rpm}$. The medium was bay water with or without phytoplankton added, or filtered seawater with phytoplankton added. Triplicate particle counts were made on each of 3 or 4 replicate bottles using a Coulter Counter Model TA-II with a $70 \mu \mathrm{m}$ orifice tube. Differences between concentrations of particles in control and experimental containers for each channel were tested for significance with Student's t-tests.

Radiolabel experiments were conducted by adding small amounts of Tetraselmis chui from labeled batch cultures in log phase to experimental containers. $T$. chui is a $20 \times 10 \mu \mathrm{m}$ flagellate that is readily consumed by both species. The goal of these experiments was to determine whether the feeding rate of either species on the labeled phytoplankton was suppressed by the presence of alternative particles, primarily detritus, in the Westermport water. The experiments were of a $2 \times 2$ factorial design: the 2 copepod species were incubated in Westernport Bay water and either Port Phillip Bay water or filtered seawater.

Adult female copepods were maintained overnight in the seawater in which they were to be incubated. Ten to 25 copepods were dispensed into $250 \mathrm{ml}$ beakers of seawater freshly strained through a $50 \mu \mathrm{m}$ mesh. After $1 \mathrm{~h}$ to allow copepods to acclimate, small amounts of the labeled phytoplankton were pipetted into each beaker. After an incubation period of 40 to $120 \mathrm{~min}$ in the dark, the copepods were strained from the water, rinsed, killed with a $5 \%$ solution of glutaraldehyde in seawater, and rinsed again in filtered seawater. Groups of 5 to 10 individuals were immediately picked out and placed in liquid scintillation vials containing 1 or $2 \mathrm{ml}$ of NCS tissue solubilizer, incubated overnight at $45^{\circ} \mathrm{C}$ to dissolve tissue, and counted on a Packard Tri-Carb liquid scintillation counter. Initial activities were determined from similar counts on copepods removed immediately after the addition of labeled phytoplankton. Counts on filtered subsamples of the labeled phytoplankton were used to calculate volume cleared by the copepods.

Egg production, growth, and development rates. Copepods were collected the day before each egg production experiment and kept overnight for acclimation in water from each bay. Water was strained through $35 \mu \mathrm{m}$ mesh to remove eggs and nauplii, and placed in $250 \mathrm{ml}$ glass reagent bottles or $4.5 \mathrm{l}$ plastic bottles. Adult female copepods were sorted under a dissecting microscope and transferred to the incubation containers; we used no more than 10 copepods per large container, or 5 for the smaller containers. After 24 $\mathrm{h}$ incubation on a wheel rotating at $1 \mathrm{rpm}$, copepods were strained from the water and preserved for counting of adults, eggs, and nauplii. The 2 species were incubated either in the same bottles or separately. A single time-series experiment revealed that overnight acclimation was sufficient to bring egg production rates to steady state.

Growth and development rate experiments were conducted by incubating an 'artificial cohort' of each species in situ for ca $48 \mathrm{~h}$ in Westernport Bay (Kimmerer \& Mckinnon 1987a). Two such experiments were conducted using both species and water from both bays.

Predation by Acartia tranteri. To test Hypothesis 3 we compared the rate of predation by adult females of A. tranteri on nauplii of Paracalanus indicus with observed growth and reproductive rates. In the first experiment we incubated adults of $P$. indicus together with 0 to 24 adult female $A$. tranteri in $250 \mathrm{ml}$ glass reagent bottles for $2 \mathrm{~d}$. After incubation samples were preserved in $2 \%$ formaldehyde, and the adults and nauplii of both species were counted. The clearance rate of adult $A$. tranteri was determined by fitting an exponential curve to the number of eggs of $P$. indicus as a function of numbers of $A$. tranteri. The equation used was:

$$
\mathrm{E}=\frac{f \mathrm{P}}{C \mathrm{~A}}\left(1-\mathrm{e}^{-c \mathrm{~A} \cdot \mathrm{T}}\right),
$$

where $E, P$, and $A=$ concentrations $\left(1^{-1}\right)$ of eggs and nauplii, $P$. indicus females, and $A$. tranteri, respectively; $f=$ fecundity (eggs female $e^{-1} \mathrm{~d}^{-1}$ ); $c=$ clearance rate $\left(\mathrm{l} \mathrm{d}^{-1}\right)$ of $A$. tranteri; and $\mathrm{T}=$ duration of the experiment (d). In the other 2 experiments we collected nauplii of $P$. indicus (mainly stages 2 to 4 ) from Port Phillip Bay with a $50 \mu \mathrm{m}$ mesh net. These were incubated for $24 \mathrm{~h}$ in lots of 10 to 30 in $250 \mathrm{ml}$ bottles with 0 to $10 \mathrm{~A}$. tranteri females.

Predation by other species. Other planktonic predators used were the copepod Tortanus barbatus, collected from Port Phillip Bay, and the scyphomedusa Catostylus mosaicus from Westernport. Although $T$. barbatus is rare in Westernport Bay, we used it as a model predatory copepod, since there are few wholly predatory copepods in the bay. A single predation experiment using $T$. barbatus was conducted by incubating 0 to 3 predators and 5 copepodites of each of 
the 2 prey species in $250 \mathrm{ml}$ bottles for $24 \mathrm{~h}$ on the rotating wheel.

Catostylus mosaicus is moderately common at times in upper Westernport Bay, and preliminary gut content analysis revealed that it preyed on copepods of the size of the 2 species under study. Predation experiments using the jellyfish were run on 3 occasions by adding a mixture of Westernport and Port Phillip plankton to $20 \mathrm{l}$ aquaria containing a single medusa $(5$ to $6 \mathrm{~cm}$ bell diameter) in filtered seawater. The plankton added was first split to provide a pair of zero-time samples and 1 or 2 experimental samples. Following incubations of up to $14 \mathrm{~h}$ the remaining prey were strained out of the water and preserved for later counting. Controls were not used, but tests of recovery after incubation revealed that over $95 \%$ of the plankton were recovered.

Fish predation experiments were conducted using juvenile yellow-eye mullet Aldrichetta forsteri or hardyhead Atherinosoma sp. Fish were collected a few days before each experiment by beach seining or dip netting in Westernport Bay, and maintained in $10 \mathrm{l}$ aquaria on a diet of natural plankton. Several kinds of experiments were run, all in $10 \mathrm{l}$ rectangular aquaria under dim room light. In the first, 1 or 2 starved fish were kept in aquaria containing filtered seawater. Equal numbers (10 to 20) of each species of copepod were added and the water was agitated with a bubbler to prevent the copepods from congregating in any part of the aquarium. Observations of each species separately in aquaria without fish revealed no tendency to aggregate. Fish were allowed to feed until a number of strikes was observed equal to half the number of copepods; then the fish were dipped out and rinsed, and the remaining copepods strained out of the water and counted. Experiments without fish usually yielded $100 \%$ recovery. When on some occasions fish refused to feed for more than $10 \mathrm{~min}$ the experiment was aborted. These experiments were run on 4 dates in early 1984 for yellow-eye mullet and 5 for hardyhead. Results were tested for significance by contingency chisquare tests. Chi-square values for heterogeneity among experiments were not significant, so we pooled results from all dates for each predator.

To assess the importance of escape response of the 2 copepod species we presented individual fish with one species of prey at a time, counted the strikes, and determined the success rate (number captured/number of strikes) on each species of copepod. Data from several dates were pooled for these experiments because heterogeneity chi-square values were not significant. In addition we conducted simulated predation experiments using a pipet attached to a siphon tube (Singarjah 1969). Copepods of both species were put in a 1 l beaker of filtered seawater, and the water with copepods was siphoned down to about $200 \mathrm{ml}$. The number of copepods remaining was used to determine a conditional capture probability for each species. This is the probability that a copepod in a small volume of water sucked out will not escape being 'captured' by the siphon. It is

$$
\mathrm{R}=\frac{\ln \left(\mathrm{N}_{\mathrm{c}} / \mathrm{N}_{\mathrm{t}}\right)}{\ln \left(\mathrm{V}_{\mathrm{C}} / \mathrm{V}_{\mathrm{t}}\right)}
$$

where $\mathrm{N}_{\mathrm{c}}=$ number of copepods captured; $\mathrm{N}_{\mathrm{t}}=$ total number of copepods; $V_{c}=$ volume of water siphoned out; and $\mathrm{V}_{\mathrm{t}}=$ total volume of water.

Tidal creek sampling. A single test of the predation hypothesis was conducted on 20 March 1985 in a field experiment similar in design to that of Carlson et al. (1984). The site for this test was Rhyll Inlet, a small tidal creek on Westernport Bay $\left(38^{\circ} 30^{\prime} \mathrm{S}, 145^{\circ} 30^{\prime} \mathrm{E}\right.$; Fig. 1). This creek is nearly empty at low tide and fills up to a distance of $2 \mathrm{~km}$ on high tide. We sampled repeatedly at the entrance of the channel and within the creek by oblique tows with a $200 \mu \mathrm{m}$ mesh, $50 \mathrm{~cm}$ diameter conical net equipped with a flow meter. Sampling began when the creek began to fill on the flood tide, and ended when water had ceased flowing out. Duplicate samples were immediately preserved for later counting and identification of plankton in subsamples.

The variable of interest was the rate of consumption (i.e. loss) of each species within the creek. We assumed that a water mass spends equal amounts of time flowing in and out of the creek, and that the clearance rate by predators is constant. The consumption rate in a water mass is the decrease in log abundance from entry to exit, divided by the time from entry to exit. The species abundance in the water entering the creek changes with the rising tide, because of the increasing proportion of oceanic water. For the entire water mass entering the creek, the mean consumption rate for the tidal period is therefore equal to half of the sum of the slopes of log abundance with time on the flood and ebb tides. Note that in the absence of consumption, the log abundance on exit is equal to that on entry, and the slopes of abundance over time should sum to zero. The consumption rates of the 2 species calculated as described above were compared by t-test using the pooled standard errors of the slopes.

In addition to plankton samples we took several samples for planktivorous fish with a beach seine just inside the inlet. Fish collected included yellow-eye mullet, hardyhead, and sandy sprat Hyperlophus vittatus. Contents of entire guts, or of $1 / 2$ or $1 / 4$ splits of the gut contents, of all planktivorous fish caught were determined and compared with ambient plankton samples taken during the hour before the fish were caught. The paracalanid species Paracalanus indicus and Bestiola similis were counted together in the guts and combined in the plankton samples for determining electivity, because they could not be distinguished reliably in the guts. 
Table 2. Characteristics of seston in Westernport and Port Phillip Bays. Values given are means and $95 \%$ confidence limits of the mean. 'Mean difference' column contains values obtained by first calculating the differences between values taken within a few days of each other, then calculating means of those differences. All differences were significantly different from 0 (paired $t$-test, $p<0.01)$

\begin{tabular}{|c|c|c|c|}
\hline Variable & Westernport & Port Phillip & Mean difference \\
\hline Dry weight, $\mathrm{mg} \mathrm{l}^{-1}$ & $15.6 \pm 5.69$ & $4.61 \pm 1.41$ & 11.1 \\
\hline Chlorophyll $a_{1} \mu \mathrm{g} \mathrm{l}^{-1}$ & $1.12 \pm 0.12$ & $1.72 \pm 0.50$ & -0.75 \\
\hline Chlorophyll:dry weight $(\times 1000)$ & $0.13 \pm 0.03$ & $0.49 \pm 0.15$ & -0.36 \\
\hline Phaeopigment, $\mu \mathrm{g} \mathrm{l}^{-1}$ & $0.47 \pm 0.15$ & $0.19 \pm 0.07$ & -0.31 \\
\hline Phaeopigment: total pigment ${ }^{a}$ & $0.26 \pm 0.01$ & $0.11 \pm 0.01$ & -0.16 \\
\hline Chlorophyll $>10 \mu \mathrm{m}$ & $0.18 \pm 0.03$ & $0.59 \pm 0.20$ & -0.31 \\
\hline Chlorophyll $>10 \mu \mathrm{m}$ : total $^{a}$ & $0.14 \pm 0.02$ & $0.35 \pm 0.07$ & -0.15 \\
\hline
\end{tabular}

\section{RESULTS}

The seston of Westernport Bay has a high proportion of detritus and a low proportion of large phytoplankton cells. Compared with Port Phillip Bay (Table 2), during 1984 Westernport Bay water contained significantly more particulate matter, significantly less chlorophyll, a higher proportion of non-living to total pigment, and a lower proportion of chlorophyll collected on a $10 \mu \mathrm{m}$ mesh. The small size of the phytoplankton in Westernport Bay was confirmed by microscopic counts of living phytoplankton cells. The numerically dominant species in Westernport Bay were small flagellates including species of Plagioselmis and Pyramimonas, and cryptomonads, mostly smaller that $5 \mu \mathrm{m}$. Dinoflagellates and diatoms were never common. In Port Phillip Bay, relatively large diatoms or dinoflagellates were always found. Common genera included Skeletonema, Chaetoceros, Phaeodactylum, Rhizosolenia, Asterionella, Leptocylindricus, and Gymnodinium.

\section{Feeding experiments}

Feeding experiments revealed that Paracalanus indicus could feed on smaller particles than Acartia tranteri (Table 3), and at a higher rate. In all 4 experiments A. tranteri either fed on particles in larger size classes than $P$. indicus, or failed to feed on the smallest sizes on which $P$. indicus could feed. In experiments with Isochrysis as food, $A$. tranteri fed at a negligible rate on this small (ca $10 \mu \mathrm{m}$ length) flagellate.

Feeding experiments using labeled Tetraselmis chui showed the higher clearance rate of Paracalanus indicus compared to that of Acartia tranteri (Table 4). They also showed no consistent trend for feeding rates to be suppressed in the detritus-rich water of Westernport compared to either Port Phillip water or filtered seawater. $A$. tranteri fed at a higher rate in Westernport water in the 29 June experiment $(t=2.89,13 \mathrm{df}, p$ $<0.01)$ but not in the March $(t=0.2,8 \mathrm{df}, p>0.1)$ or 14 June $(t=0.8,14 \mathrm{df}, p>0.1)$ experiments. $P$. indicus fed at a higher rate in filtered seawater on 29 June $(t=$ $2.16,14 \mathrm{df}, p<0.05$ ) and at similar rates between the 2 treatments on 1 March $(t=1.2,8 \mathrm{df}, p>0.1)$ and 14 June $(t=1.1,14 \mathrm{df}, p>0.1)$.

\section{Egg production, growth, and development rates}

Results of egg production experiments were similar to those for feeding (Table 5). Usually both species produced eggs at a higher rate in Port Phillip water than in water from Westernport. The egg production rate of Paracalanus indicus was usually higher than that of Acartia tranteri in a given treatment, and sometimes considerably higher. Analysis of variance of log-transformed egg production rates showed no significant interaction term between species and bays $\left(F_{1,153}=1.1\right.$, $p>0.1$ ). This shows that the 2 species suffered the same proportional reduction in egg production rate in Westernport water relative to water from Port Phillip Bay.

Growth and development rates of the 2 species were measured on 2 occasions (Table 6). In both cases the growth rate of Paracalanus indicus was substantially higher than that of Acartia tranteri, although the development rate of $P$. indicus was significantly higher only on 20 June. In neither experiment did final log mean weights (and therefore growth and development rates) of either species differ significantly between the 2 treatments.

\section{Predation}

The median clearance rate for Acartia tranteri preying on nauplii of Paracalanus indicus was $33 \mathrm{ml}$ female ${ }^{-1} \mathrm{~d}^{-1}$. Individual experimental rates were $23 \pm$ 
Table 3. Summary of results of feeding experiments on Acartia tranteri and Paracalanus indicus. X indicates significant feeding $(t$-test, $p<0.05)$ in each channel; blank indicates no significant feeding. ESD: Equivalent Spherical Diameter. Dashed lines indicate approximate size range of any food added

\begin{tabular}{|c|c|c|c|c|c|c|c|c|c|c|}
\hline $\begin{array}{l}\text { Channel: } \\
\text { ESD }(\mu \mathrm{m}):\end{array}$ & $\begin{array}{l}5 \\
2.5\end{array}$ & $\begin{array}{l}6 \\
3.2\end{array}$ & $\begin{array}{l}7 \\
4.0\end{array}$ & $\begin{array}{l}8 \\
5.1\end{array}$ & $\begin{array}{l}9 \\
6.4\end{array}$ & $\begin{array}{l}10 \\
8.1\end{array}$ & $\begin{array}{l}11 \\
10.2\end{array}$ & $\begin{array}{l}12 \\
12.8\end{array}$ & $\begin{array}{l}13 \\
16.1\end{array}$ & $\begin{array}{l}14 \\
20.3\end{array}$ \\
\hline \multicolumn{11}{|c|}{ Experiment A: Isochrysis and Tetraselmis in filtered seawater } \\
\hline Paracalanus & & $\mathrm{x}$ & $\mathrm{X}$ & & $\mathrm{x}$ & $\mathrm{x}$ & & & & \\
\hline Acartia & & & $\mathrm{x}$ & & $\mathrm{X}$ & $\mathrm{X}$ & & & & \\
\hline Food added & & & & & & & & & & \\
\hline \multicolumn{11}{|c|}{ Experiment B: Isochrysis in Westernport water } \\
\hline Paracalanus & $\mathrm{x}$ & $\mathrm{X}$ & $\mathrm{X}$ & & & & & & & \\
\hline Acartia & & & & & & $\mathrm{X}$ & $x$ & $x$ & $\mathrm{X}$ & $\mathrm{X}$ \\
\hline Food added & $\cdots$ & & 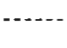 & & & & & & & \\
\hline \multicolumn{11}{|c|}{ Experiment C: Westernport water } \\
\hline Paracalanus & & & & $\mathrm{x}$ & $\mathrm{X}$ & $\mathrm{X}$ & $\mathrm{X}$ & & & $\mathrm{x}$ \\
\hline Acartia & & & & & & & & $\mathrm{x}$ & $\mathrm{x}$ & $\mathrm{X}$ \\
\hline \multicolumn{11}{|c|}{ Experiment C: Port Phillip water } \\
\hline Paracalanus & $\mathrm{x}$ & $x$ & $\mathrm{x}$ & $\mathrm{X}$ & $\mathrm{x}$ & $\mathrm{x}$ & $\mathrm{x}$ & $\mathrm{X}$ & $\mathrm{X}$ & $\mathrm{x}$ \\
\hline Acartia & & & $\mathrm{X}$ & $x$ & $x$ & $x$ & $\mathrm{X}$ & $x$ & $\mathrm{x}$ & $x$ \\
\hline \multicolumn{11}{|c|}{ Experiment D: Tetraselmis in filtered seawater } \\
\hline Paracalanus & & & & $\mathrm{X}$ & $\mathrm{X}$ & $x$ & & & & \\
\hline Acartia & & & & $\mathrm{X}$ & $\mathrm{x}$ & $x$ & $\mathrm{X}$ & & & \\
\hline Food added & & & & $-\cdots$ & & & & & & \\
\hline \multicolumn{11}{|c|}{ Experiment D: Tetraselmis in Westernport water } \\
\hline Paracalanus & & $\mathrm{x}$ & $\mathrm{X}$ & $\mathrm{X}$ & $\mathrm{X}$ & $\mathrm{x}$ & & & & \\
\hline Acartia & & & & $\mathrm{X}$ & $\mathrm{X}$ & $\mathrm{x}$ & $\mathrm{X}$ & & & \\
\hline
\end{tabular}

Table 4. Summary of feeding experiments using radiolabeled phytoplankton. Values are mean and $95 \%$ confidence limits of clearance rate, $\mathrm{ml}$ copepod $\mathrm{d}^{-1} \mathrm{~d}^{-1}$. WP: treatments with Westernport water, FS/PP: treatments with filtered seawater (June experiments) or Port Phillip water (March experiment)

\begin{tabular}{|lcrrrrr}
\hline Date & \multicolumn{2}{c}{ Acartia tranteri } & \multicolumn{2}{c}{ Paracalanus indicus } & \multicolumn{2}{c|}{ Differences } \\
& WP & FS/PP & WP & FS/PP & WP & FS/PP \\
\hline 1 Mar 1984 & $2.78 \pm 2.50$ & $2.56 \pm 1.05$ & $10.84 \pm 2.32$ & $8.75 \pm 2.50$ & $7.08 \pm 1.86$ & $6.10 \pm 3.13$ \\
14 Jun 1984 & $1.93 \pm 0.50$ & $1.64 \pm 0.49$ & $3.02 \pm 0.77$ & $2.49 \pm 0.38$ & $1.08 \pm 0.60$ & $0.70 \pm 0.83$ \\
29 Jun 1984 & $1.90 \pm 0.30$ & $1.11 \pm 0.37$ & $10.01 \pm 1.87$ & $15.05 \pm 3.68$ & $7.48 \pm 1.58$ & $13.94 \pm 3.47$ \\
\hline
\end{tabular}

Table 5. Summary of egg production rate experiments on Acartia tranteri and Paracalanus indicus. Values are means leggs female ${ }^{-1} \mathrm{~d}^{-1}$ ) and $95 \%$ confidence limits of the mean

\begin{tabular}{|c|c|c|c|c|c|c|}
\hline \multirow[t]{2}{*}{ Date of experiment } & \multicolumn{2}{|c|}{ Acartia tranteri in water from } & \multicolumn{4}{|c|}{ Paracalanus indicus in water from } \\
\hline & WP & PP & Diff. & WP & $\mathrm{PP}$ & Diff. \\
\hline 2 May 1984 & $11.4 \pm 3.4$ & $10.9 \pm 1.5$ & -0.5 & $10.5 \pm 1.8$ & $42.5 \pm 13.5$ & 32.1 \\
\hline 15 May 1984 & $0.5 \pm 0.3$ & $4.4 \pm 1.2$ & 3.9 & $1.3 \pm 0.7$ & $6.7 \pm 2.2$ & 5.4 \\
\hline 30 May 1984 & $0.4 \pm 0.2$ & $7.2 \pm 1.3$ & 6.8 & $4.2 \pm 1.6$ & $14.7 \pm 2.3$ & 10.5 \\
\hline 6 Jun 1984 & $0.8 \pm 0.4$ & $5.7 \pm 1.0$ & 4.9 & $5.2 \pm 2.2$ & $22.0 \pm 6.5$ & 16.8 \\
\hline 3 Jul 1984 & $2.0 \pm 0.9$ & $4.0 \pm 1.8$ & 2.0 & $7.0 \pm 1.7$ & $20.3 \pm 10.9$ & 13.3 \\
\hline 30 Oct 1984 & $0.4 \pm 0.4$ & $0.8 \pm 0.5$ & 0.4 & $2.5 \pm 0.8$ & $9.8 \pm 1.1$ & 7.3 \\
\hline 5 Dec 1984 & $3.9 \pm 3.3$ & $6.6 \pm 5.3$ & 2.7 & $4.8 \pm 4.5$ & $15.1 \pm 13.0$ & 10.2 \\
\hline 22 Jan 1985 & $10.8 \pm 2.6$ & $8.0 \pm 3.0$ & -2.8 & $9.9 \pm 2.5$ & $7.5 \pm 3.6$ & -2.5 \\
\hline Mean & 3.8 & 5.9 & 2.2 & 5.7 & 17.3 & 11.6 \\
\hline $\mathrm{SD}$ & 4.7 & 3.0 & 3.1 & 3.3 & 11.6 & 10.1 \\
\hline
\end{tabular}


Table 6. Rates of growth $\left(d^{-1}\right)$ and development (stage $d^{-1}$ ) and final log mean weights ( $\mu$ g per copepod) (means $\pm 95 \%$ CL) for Acartia tranteri and Paracalanus indicus in Westernport and Port Phillip water. $t$-tests test the significance of the difference in final log mean weights of a species between treatments

\begin{tabular}{|c|c|c|c|c|}
\hline & \multicolumn{2}{|c|}{ Acartia } & \multicolumn{2}{|c|}{ Paracalanus } \\
\hline & WP & $\mathrm{PP}$ & $W P$ & $P P$ \\
\hline \multicolumn{5}{|l|}{16 April 1984} \\
\hline Growth rate & $0.10 \pm 0.04$ & $0.14 \pm 0.03$ & $0.22 \pm 0.04$ & $0.21 \pm 0.03$ \\
\hline Development rate & $0.30 \pm 0.12$ & $0.42 \pm 0.09$ & $0.45 \pm 0.08$ & $0.43 \pm 0.06$ \\
\hline Final log mean weight & $0.03 \pm 0.07$ & $0.11 \pm 0.04$ & $0.69 \pm 0.06$ & $0.68 \pm 0.05$ \\
\hline Difference & \multicolumn{2}{|c|}{0.07} & \multicolumn{2}{|c|}{-0.01} \\
\hline Degrees of freedom & \multirow{2}{*}{\multicolumn{2}{|c|}{$\begin{array}{l}7 \\
1.78\end{array}$}} & \multirow{2}{*}{\multicolumn{2}{|c|}{$\begin{array}{c}8 \\
-0.28\end{array}$}} \\
\hline$t$-value & & & & \\
\hline \multicolumn{5}{|l|}{20 Jun 1984} \\
\hline Growth rate & $0.04 \pm 0.01$ & $0.05 \pm 0.01$ & $0.14 \pm 0.03$ & $0.13 \pm 0.02$ \\
\hline Development rate & $0.11 \pm 0.03$ & $0.14 \pm 0.03$ & $0.28 \pm 0.06$ & $0.26 \pm 0.04$ \\
\hline Final log mean weight & $-0.25 \pm 0.02$ & $-0.24 \pm 0.02$ & $0.38 \pm 0.15$ & $0.36 \pm 0.03$ \\
\hline Difference & \multicolumn{2}{|c|}{0.02} & \multicolumn{2}{|c|}{-0.02} \\
\hline Degrees of freedom & \multicolumn{2}{|c|}{7} & \multicolumn{2}{|c|}{7} \\
\hline$t$-value & \multicolumn{2}{|c|}{1.26} & \multicolumn{2}{|c|}{-1.21} \\
\hline
\end{tabular}

Table 7 Catostylus mosaicus. Predation on Acartia tranteri, Paracalanus indicus, and total zooplankton. Data presented are numbers in control samples (means of 2) and percent eaten by 1 or 2 medusae (A and B) on 3 dates

\begin{tabular}{|c|c|c|c|}
\hline & \multirow[t]{2}{*}{ Number in control samples } & \multicolumn{2}{|c|}{ Percent consumed } \\
\hline & & A & $B$ \\
\hline \multicolumn{4}{|l|}{1 Feb 1985} \\
\hline Acartia & 100 & $62 \%$ & - \\
\hline Paracalanus & 81 & $58 \%$ & - \\
\hline Total zooplankton & 596 & $37 \%$ & - \\
\hline \multicolumn{4}{|l|}{11 Feb 1985} \\
\hline Acartia & 130 & $91 \%$ & $82 \%$ \\
\hline Paracalanus & 29 & $97 \%$ & $79 \%$ \\
\hline Total zooplankton & 1130 & $92 \%$ & $73 \%$ \\
\hline \multicolumn{4}{|l|}{14 Feb 1985} \\
\hline Acartia & 90 & $9 \%$ & $17 \%$ \\
\hline Paracalanus & 64 & $33 \%$ & $67 \%$ \\
\hline Total zooplankton & 1220 & $19 \%$ & $24 \%$ \\
\hline \multicolumn{4}{|c|}{ Median percent consumed: } \\
\hline Acartia & $62 \%$ & & \\
\hline Paracalanus & $58 \%$ & & \\
\hline Total zooplankton & $37 \%$ & & \\
\hline
\end{tabular}

$6,33 \pm 4$, and $40 \pm 13$ (mean $\pm 95 \%$ confidence limits\}. We did not measure the predation rate of A. tranteri on its own nauplii.

Predation rates of Tortanus barbatus on copepodites of the 2 species did not show selectivity. In 15 experimental containers with 2 or $3 T$. barbatus each, a total of 27 Acartia tranteri and 28 Paracalanus indicus were consumed. Similarly, predation by Catostylus mosaicus was apparently not selective (Table 7 ). The median percent consumed was $62 \%$ for $A$. tranteri and $58 \%$ for $P$. indicus.

Predation by planktivorous fish, however, showed considerable selectivity. In the first set of experiments, in which both prey species were offered together, the proportion of Acartia tranteri consumed was significantly lower than the proportion of Paracalanus indicus (Table 8). With either fish species as predator, the rate of consumption of $P$. indicus was slightly more than twice that of $A$. tranteri. $P$. indicus is very close to A. tranteri in size but is somewhat more visible because of its large yellow oil droplet. However, at least part of the difference in consumption rates was due to a difference in escape responses of the prey In the experiments with the 2 prey offered separately, the predator was successful in capturing $A$. tranteri in $59 \%$ of the attacks, and in capturing $P$. indicus in $81 \%$ of the 
attacks (Table 9). The difference was further attributed to escape responses by the results of the simulated predation experiments (Table 10). The number of

Table 8. Summary of predation experiments using fish as predators. Two species of prey offered simultaneously

\begin{tabular}{|c|c|c|c|}
\hline & \multicolumn{2}{|c|}{ Nos after 15 attacks } & \multirow[t]{2}{*}{ Chi-square } \\
\hline & Acartia & Paracalanus & \\
\hline \multicolumn{4}{|l|}{ Hardyhead } \\
\hline No. of trials & 14 & 14 & \\
\hline Total offered & 210 & 210 & \\
\hline No. remaining & 145 & 74 & \\
\hline \multirow[t]{2}{*}{ No. eaten } & 65 & 136 & $46.75^{\cdots}$ \\
\hline & \multicolumn{2}{|c|}{ Heterogeneity Chi-square: } & 3.29 NS \\
\hline \multicolumn{4}{|c|}{ Yellow-eye mullet } \\
\hline No. of trials & 15 & 15 & \\
\hline Total offered & 200 & 200 & \\
\hline No. remaining & 139 & 63 & \\
\hline No. eaten & 61 & 137 & $56.26^{\cdots}$ \\
\hline & \multicolumn{2}{|c|}{ Heterogeneity Chi-square: } & $1.00 \mathrm{NS}$ \\
\hline \multicolumn{4}{|c|}{ - Difference significant at $p<0.01$} \\
\hline \multicolumn{4}{|c|}{ NS: difference not significant, $p>0.05$} \\
\hline
\end{tabular}

Table 9. Results of predation experiments in which fish were presented one prey at a time. The difference between the predation rates on the 2 species was significant (Chi-square $=$ 9.63, $p<0.005$ )

\begin{tabular}{|lcrrrr|}
\hline & $\begin{array}{c}\text { No. of } \\
\text { trials }\end{array}$ & $\begin{array}{c}\text { Total } \\
\text { attacks }\end{array}$ & Eaten & Missed & $\begin{array}{c}\text { Percent } \\
\text { successful }\end{array}$ \\
\hline Acartia & 5 & 75 & 44 & 31 & $59 \%$ \\
Paracalanus & 7 & 105 & 85 & 20 & $81 \%$ \\
Total & & 180 & 129 & 51 & $72 \%$ \\
\hline
\end{tabular}

$P$. indicus captured in all trials was close to that expected by chance, while $A$. tranteri was captured at only half the rate. The conditional capture probability, the chance that a copepod will be siphoned off if it encounters the siphon stream, was close to 1 for $P$. indicus but only 0.32 for A. tranteri.

\section{Tidal creek sampling}

Species present in the tidal creek sampling effort included the species studied here as well as bay residents including Pseudodiaptomus cornutus, Parvocalanus crassirostris, and Bestiola similis. Total zooplankton abundance rose slightly on the incoming tide, then decreased sharply near the end of the ebb (Fig. 2). The abundance of Acartia tranteri decreased, and that of Paracalanus indicus increased, during the rising tide, since water entering the creek had an increasing contribution from the ocean. On the ebb tide, A. tranteri increased, then decreased in abundance, while the abundance of $P$. indicus decreased sharply from about $1 \mathrm{~h}$ after slack water. The final abundance of $P$. indicus was about 50 -fold lower than its average abundance on the flood. Samples taken within the creek confirmed that the species collected at the mouth were being swept into the creek, so changes in abundance between flood and ebb tides could be attributed to mortality.

Mean consumption rates within the creek were highest for adults and copepodites of Paracalanus indicus and lowest for Pseudodiaptomus adults (Table 11). Mortality rates were significantly higher for adults of $P$. indicus than for Acartia tranteri $(t=2.01,36 \mathrm{df}$,

Table 10. Summary of simulated predation experiments

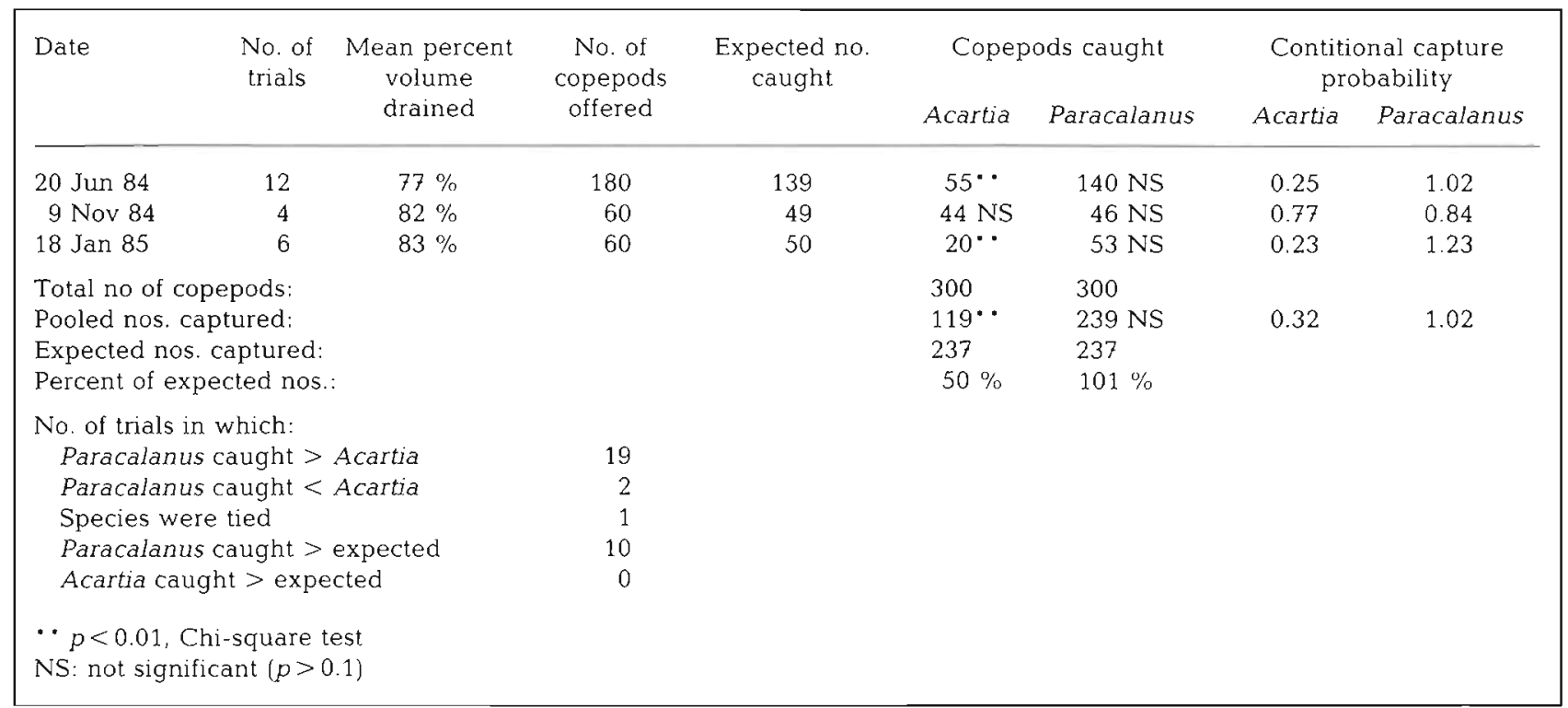




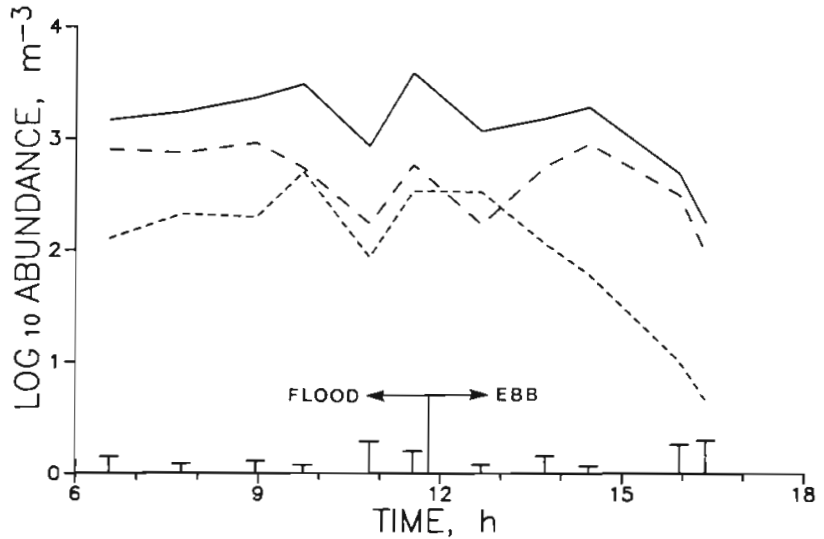

Fig. 2. Tidal creek field experiment. Mean abundances of total zooplankton (-), Acartia tranteri (-- ), and Paracalanus indicus (-..-). The $95 \%$ confidence intervals for the graphed means, shown at the bottom, were determined from the error mean square in an analysis of variance including log-transformed abundances of both species and the total
Table 11. Mortality rates of common species of zooplankton during the tidal creek experiment. Values given are mean mortality rates $\left(\mathrm{h}^{-1}\right)$ and $95 \%$ confidence limits
Pseudodiaptomus adults

Parvocalanus crassirostris

Acartia tranteri adults

Total copepods

Total zooplankton

Acartia tranteri copepodites

Pseudodiaptomus copepodites

Bestiola similis copepodites

Bestiola similis adults

Oikopleura dioica

Euterpina acutifrons

Paracalanus indicus copepodites

Paracalanus indicus adults
$-0.10 \pm 0.41$

$0.03 \pm 0.30$

$0.17 \pm 0.24$

$0.23 \pm 0.21$

$0.24 \pm 0.20$

$0.26 \pm 0.25$

$0.26 \pm 0.56$

$0.28 \pm 0.24^{\circ}$

$0.31 \pm 0.27^{\circ}$

$0.32 \pm 0.32^{\circ}$

$0.34 \pm 0.14$

$0.41 \pm 0.20^{\circ}$

$0.53 \pm 0.20^{\circ}$
- Mortality significantly different from $0(p<0.05)$

Table 12. Acartia and Paracalanidae in fish gut contents and in water. The columns 'Proportion of Acartia' give the ratio of this species to the total of Acartia and Paracalanidae only. Difference between arc-sine transformed proportions of the 2 taxa excluding guts containing fewer than 10 of the 2 taxa, was significant at $\mathrm{p}<0.01$ (signed-rank test, $N=18$, sum of ranks $=17$ ).

Fish examined were hardyhead (HH), yellow-eye mullet (YEM), and sandy sprat (SS)

\begin{tabular}{|c|c|c|c|c|c|c|}
\hline \multirow[t]{2}{*}{ Time (h) } & \multirow[t]{2}{*}{ Fish } & \multicolumn{2}{|c|}{ Gut contents } & \multicolumn{2}{|c|}{ Proportion of Acartia } & \multirow{2}{*}{$\begin{array}{c}\text { Arc-sine } \\
\text { transformed } \\
\text { difference }\end{array}$} \\
\hline & & Acartia & Paracalanidae & In guts & In water & \\
\hline $12: 20$ & $\mathrm{HH}$ & 0 & 6 & & & \\
\hline $12: 20$ & $\mathrm{HH}$ & 0 & 0 & & & \\
\hline $12: 20$ & $\mathrm{HH}$ & 0 & 31 & 0.00 & 0.21 & -0.48 \\
\hline $12: 20$ & $\mathrm{HH}$ & 1 & 43 & 0.02 & 0.21 & -0.33 \\
\hline $12: 20$ & $\mathrm{HH}$ & 1 & 17 & 0.06 & 0.21 & -0.24 \\
\hline $12: 20$ & $\mathrm{HH}$ & 0 & 52 & 0.00 & 0.21 & -0.48 \\
\hline $12: 20$ & YEM & 0 & 14 & 0.00 & 0.21 & -0.48 \\
\hline $12: 20$ & YEM & 1 & 10 & 0.09 & 0.21 & -0.17 \\
\hline $15: 30$ & $\mathrm{HH}$ & 0 & 8 & & & \\
\hline $15: 30$ & $\mathrm{HH}$ & 0 & 0 & & & \\
\hline $15: 30$ & $\mathrm{HH}$ & 0 & 0 & & & \\
\hline $15: 30$ & $\mathrm{HH}$ & 0 & 32 & 0.00 & 0.76 & -1.06 \\
\hline $15: 30$ & $\mathrm{HH}$ & 5 & 22 & 0.19 & 0.76 & -0.61 \\
\hline $15: 30$ & YEM & 95 & 6 & 0.94 & 0.76 & 0.27 \\
\hline $15: 30$ & YEM & 51 & 4 & 0.93 & 0.76 & 0.24 \\
\hline $16: 45$ & $\mathrm{HH}$ & 5 & 58 & 0.08 & 0.91 & -0.99 \\
\hline $16: 45$ & $\mathrm{HH}$ & 7 & 22 & 0.24 & 0.91 & -0.76 \\
\hline $16: 45$ & SS & 40 & 2 & 0.95 & 0.91 & 0.08 \\
\hline $16: 45$ & SS & 30 & 3 & 0.91 & 0.91 & -0.01 \\
\hline $16: 45$ & $\mathrm{SS}$ & 28 & 3 & 0.90 & 0.91 & -0.02 \\
\hline $16: 45$ & YEM & 3 & 0 & & & \\
\hline $16: 45$ & YEM & 14 & 16 & 0.47 & 0.91 & -0.52 \\
\hline $16: 45$ & YEM & 1 & 0 & & & \\
\hline $16: 45$ & YEM & 5 & 9 & 0.36 & 0.91 & -0.63 \\
\hline $16: 45$ & YEM & 9 & 3 & 0.75 & 0.91 & -0.22 \\
\hline
\end{tabular}

$p<0.05)$, but not for copepodites $(t=0.90, p>0.1)$. For all stages of these species pooled, the difference was significant $(t=2.02, p<0.05)$.

Although the reduction in numbers of the zooplankton in the tidal creek could not be unequivocally attributed to vertebrate predation, this is the most likely source: no other likely predator was observed in the creek. Three seine sets collected a total of 25 fish of 3 species: hardyhead, yellow-eye mullet, and sandy sprat. Gut contents of these fish were highly variable, although 
sandy sprat, collected in only one set, appeared to consume Acartia tranteri in higher proportions than did the other fish (Table 12). A. trantericomprised 0 to $47 \%$ of the total in any one gut, and Paracalanidae comprised 0 to $88 \%$. However, paracalanid copepods occurred significantly more frequently in the guts than predicted from their abundance in the water relative to $A$. tranteri $(p<0.01$, signed rank test).

\section{DISCUSSION}

\section{Feeding}

The size selectivity experiments showed that Paracalanus indicuscan eat food of a smaller size than Acartia tranteri: although the size ranges overlapped considerably, $P$. indicus was always better at consuming the smallest particles measured. A similar relationship has been shown for P. parvus and A. tonsa (Bartram 1981). Given the size distribution of chlorophyll and the relative paucity of large cells in water from Westernport Bay, one would predict that $P$. indicus would be better than $A$. tranteri at consuming phytoplankton there.

The radiolabel experiments showed further that neither species had significant difficulty in collecting food from the milieu of detrital particles in water from Westernport. Although the cells used were somewhat larger than most of what is usually found in Westernport water, they were close to the lower size limit of particles on which Acartia tranteri can feed.

A further result of the feeding experiments was that Paracalanus indicus fed at a much higher rate then Acartia tranteri. Mullin \& Evans (1974) found that $P$. parvus turned over food at a higher rate than $A$. tonsa, although at a somewhat lower efficiency. Interestingly, in their experiment, run in a deep tank without planktivorous fish, $P$. parvus replaced $A$. tonsa as the numerical dominant (Mullin \& Evans 1974).

Based on these feeding experiments alone, Paracalanus indicus should be able to maintain a higher rate of reproduction than Acartia tranteri, even at a lower growth efficiency. If development and mortality rates had been equal, then, $P$. indicus should have been the numerical dominant in Westernport Bay; thus Hypothesis 1 can be rejected.

\section{Reproductive and growth rates}

Both species of copepod usually had a lower egg production rate in water from Westernport than in water from Port Phillip Bay. Since the clearance rates were not much affected by the detrital content of the water this implies that, as expected, the food was less abundant or less suitable for copepod reproduction. However, the hypothesized effect did not materialize: the ratios of egg production rates in the 2 bays did not differ between the 2 species. Furthermore, Paracalanus indicus had a higher egg production rate than Acartia tranteri in water from Westernport.

Growth and development rates did not differ between treatments for either species. Since growth rate can respond fairly rapidly to increases in food supply (Kimmerer \& McKinnon 1987a), any substantial reduction in food quality should manifest itself in a reduced growth rate. The lack of difference in growth rate between incubations in Port Phillip water and Westernport water for either species suggests that the reduction in food quality for reproduction by adults may not hold for growth rate of juveniles. The growth rate of Paracalanus indicus was substantially higher than that of Acartia tranteri in both experiments, partly because of a greater weight gain per stage and partly because of more rapid development. The life stages used in these experiments were late copepodites, which develop much more slowly than the earlier stages in Paracalanus but not in Acartia (Landry 1983). Based on these results we can conclude that $P$. indicus would have a more rapid development rate from egg to adult than $A$. tranteri in Westernport Bay.

Neither the egg production nor growth rate experiments supported Hypothesis 2, which was therefore rejected.

\section{Predation by Acartia tranteri}

Species of Acartia are known to be omnivorous, preying on early nauplii of their own and other species of copepod as well as on other microzooplankton (Petipa et al. 1970, Landry 1978, Lonsdale et al. 1979, Fulton 1984a). Predation by Acartia has been implicated in the distribution of a species of prey copepod in an Australian estuary (Rippingale \& Hodgkin 1974).

The clearance rate of Acartia tranteri in 3 predation experiments had a median value of $33 \mathrm{ml} \mathrm{copepod}^{-1}$ $\mathrm{d}^{-1}$, which is similar to results of other predation experiments (Landry 1978, Lonsdale et al. 1979, Stoecker \& Egloff 1987). The effect of this level of predation on the Paracalanus indicus population can be calculated from data on abundances of these predators in Westernport Bay. The mean density of copepodites and adults of A. tranteri in the eastern part of the bay was about $21^{-1}$, of which about $1 / 4$ were adults (Kimmerer \& McKinnon $1978 b)$. The clearance of copepodites of A. clausi was only $1 / 4$ that of adults (Landry 1978). If we assume conservatively that the median clearance rate of the population was $1 / 2$ that of the adults, then the overall clearance rate of the population was about $3 \% \mathrm{~d}^{-1}$. 
Early nauplii (Stages 1 to 3 ) made up $40 \%$ (median; range 30 to $49 \%$ ) of the Paracalanus indicus population on the 3 occasions on which it was determined. Acartia tranteri therefore consumes about $1 \% \mathrm{~d}^{-1}$ of the entire population, clearly a minor source of mortality. For comparison, the mortality rate of early $A$. tranteri nauplii was about $16 \% \mathrm{~d}^{-1}$ on average (Kimmerer \& McKinnon 1987a); since $P$. indicus nauplii are about the same size, mortality rates should be comparable. In addition, this analysis does not take into account cannibalism by $A$. tranteri, which could be considerable (Landry 1978). We therefore reject Hypothesis 3.

\section{Predation by invertebrate predators}

As we have noted before (Kimmerer \& McKinnon 1985), the plankton of Westernport Bay contains few planktivorous species. Furthermore, we have observed no benthic species in the area capable of consuming large numbers of zooplankton. The low mortality rates of Acartia tranteri (Kimmerer \& McKinnon 1987a) also support our claim that the predatory environment in Westernport Bay is fairly benign. We ran experiments using invertebrate predators mainly to attempt to rule out planktonic predators as a significant selective factor. The jellyfish Catostylus mosaicus can prey heavily on copepods but is not particularly abundant, and showed no preference for either prey species. Tortanus barbatus was used as a model predatory copepod that feeds on larger prey than does Acartia (Mullin 1979); it too showed no preference for one prey species over the other. In the absence of differential predation by these species at least, there is no support for a mechanism involving invertebrate predators.

\section{Predation by fish}

In contrast to other predators, small fish showed a substantial difference in the rates of predation on the 2 species of copepod. This difference was consistent in experiments of 2 kinds with 2 species of predator, and supported to some extent by the field experiment. In each case Paracalanus indicus was 'preferred' over Acartia tranteri, generally by a ratio of about $2: 1$. The difference apparently comes in the encounter and attack components of the predatory interaction (Gerritsen \& Strickler 1977). A. tranteri has advantages in both of these phases. Encounter occurs through visual detection of the copepod by the fish; A. tranteri is less visible, at least to the human eye, and is therefore less likely to be detected (Zaret \& Kerfoot 1975). Once detected, $A$. tranteri is better able to avoid capture by a sucking planktivore, resulting in a lower success rate (by fish or pipets) in the attack phase.
Similar results were obtained in predation experiments using juvenile yellow-eye mullet fed Acartia tranteri and Pseudodiaptomus cornutus (Fancett \& Kimmerer 1985). P. cornutus is larger and much more visible than $A$. tranteri, so the difference in those experiments was largely due to differences in visibility.

In the field experiment the overall mortality rate of Paracalanus indicus was roughly twice that of Acartia tranteri during the tidal excursion up the creek. This was probably due to fish predation, although other possibilities cannot be ruled out. No concentration of planktonic predators was observed in any sample, and given the mud bottom and wide, intertidal depth range of the creek, it is unlikely that a benthic predator on adult copepods would be abundant. Mysids are likely suspects, but no mysids were found in any of our 54 samples. Another possibility is stranding of $P$. indicus on the tidal flats, but we know of no evidence that this could happen. Therefore we conclude by process of elimination that the bulk of the mortality occurring during this period was due to fish predation.

To some extent the gut content data show the expected prey selection, although the large variability in the results makes interpretation difficult. Overall the fish showed a preference for Paracalanus indicus over Acartia tranteri, except possibly for the 3 sandy sprat collected. Of the 3 species collected, only the hardyhead and yellow-eye mullet are known to be common in the bay (Robertson 1980). In other studies of feeding by planktivorous fish. $A$. tranteri has only rarely been consumed. The resident fish of an eelgrass bed consumed mostly Pseudodiaptomus and hardly any $A$. tranteri (Robertson \& Howard 1978), while 3 species of pipefish contained no copepods identified as $A$. tranteri (Howard \& Koehn 1985).

The rate of consumption in the tidal creek seems high. We extrapolated the overall mortality rates due to consumption to the entire upper bay, assuming that the rate would be the same in all intertidal areas. The volume of water in these areas is about $11 \%$ of the volume of the upper bay, based on a $2 \mathrm{~m}$ tidal range and measurements made on bathymetric charts. Assuming that the mortality rates in Table 11 apply for $12 \mathrm{~h}$ per day, Acartia tranteri copepodites and adults should have a mortality rate due to loss in shallow waters of about $27 \% \mathrm{~d}^{-1}$, while Paracalanus indicus copepodites should have a mortality rate of $54 \% \mathrm{~d}^{-1}$ and adults $70 \% \mathrm{~d}^{-1}$. The median mortality rate of A. tranteri adults in summer was $19 \% \mathrm{~d}^{-1}$, and for copepodites, $5 \% \mathrm{~d}^{-1}$ (Kimmerer \& McKinnon 1987a). Therefore it is probably not true that predation rates in all intertidal areas are the same as those observed in tidal channels. Much of the intertidal area is in the broad expanses of mud flat in the northern part of the 
bay, where predation rates are probably much less than in small, dynamic areas such as this channel.

The evidence we have provided is circumstantial: the mortality rates in the creek could not be attributed unequivocally to fish predation, and we have no data on predation rates or abundances of fish. Nevertheless, the results are consistent with the hypothesis that predation by visually selective planktivores provides enough differential mortality to explain the overwhelming dominance of Acartia tranteri over Paracalanus indicus in Westernport Bay. This suggestion complements the recent findings of Paffenhöfer \& Stearns (1988) on the relative abundance of these 2 genera in offshore waters: Paracalanus sp. can obtain sufficient food at the low food concentrations found in offshore waters, while Acartia tonsa cannot.

Other species may be excluded from Westernport Bay by a different mechanism. Several species of Cladocera are abundant in Bass Strait but virtually absent even in the entrance channel of the Bay (Kimmerer \& McKinnon 1985). The distribution of these species suggests that, unlike Paracalanus indicus, they are excluded by a mechanism occurring offshore, such as in the zone where bay and neritic waters mix. Podon intermedius and probably the other species of Podon and Evadne feed entirely on large particles (Jagger et al. 1988), which may be too rare in Westernport Bay for these species to maintain their populations.

\section{Influence of predation}

Several common features of shallow-water plankton are believed to be a defense against visual or sizeselective predators, implying that visual predation is important in shallow waters. These include small size (e.g. Oithona species, Parvocalanus crassirostris; Fulton 1984a), demersal behavior (e.g. Pseudodiaptomus sp.; Vuorinen et al. 1983, Fancett \& Kimmerer 1985, Fulton 1985), and isochronal development in Acartia species, which may be a mechanism for delaying growth to large size in an environment of high visual predation pressure (Miller et al. 1977). In offshore waters, predators tend less often to be visually selective planktivores and more often to include fish having nonvisual mechanisms of prey selection (Leong \& $\mathrm{O}^{\circ} \mathrm{Con}-$ nell 1969, Durbin \& Durbin 1975).

Fulton (1984b) found that Acartia tonsa, numerically dominant in an estuary by virtue of its high growth rate, was prevented from achieving this dominance in summer by fish predation. The apparent discrepancy between Fulton's (1984b) results and our own can readily be resolved. Fulton's experiments compared predation rates on Acartia tonsa, Parvocalanus crassirostris, and other resident fauna, but did not include non- resident species from the neritic zone. Thus the questions being asked were different in the 2 studies.

The observed distribution of plankton species in Westernport Bay is typical of temperate bays, where a species of Acartia is often numerically dominant or codominant, and neritic species are excluded. This occurs both in bays of low productivity such as Westernport, and in high-productivity locations (e.g. Jakle's Lagoon; Landry 1978). Any general explanation of this pattern must account for its ubiquity.

We offer the following general hypothesis about the influence of predation on bay zooplankton. Shallow water provides shelter for small planktivorous fish, increasing their abundance per unit volume (Robertson 1980). Therefore visually oriented predation is more common relative to other modes of predation in shallow water than in deep water. The effect of this is to favor those species that can maintain a high growth rate while at the same time avoiding much of the predation. This applies irrespective of the nutritive status of the water, since the mechanism is more related to mean depth than any other feature of bays.

Acknowledgements. This project was funded by Australian Marine Science and Technology Grant 83/1325R. We thank K. M. Ough for assistance in experimental work and analysis; R. Wetherbee and D. Hill for identifying phytoplankton; and G.P. Jenkins, W. T. Peterson, and A.I. Robertson for critical reviews of the manuscript.

\section{LITERATURE CITED}

Alldredge, A. L. (1984). The quantitative significance of gelatinous zooplankton as pelagic consumers. In: Fasham, M. J. R. (ed.) Flows of energy and materials in marine ecosystems. Plenum, New York, p. 407-433

Alldredge, A. L., King, J. M. (1980). Effects of moonlight on the vertical migration patterns of demersal zooplankton. J. exp. mar. Biol. Ecol. 44: 133-156

Barlow, J. P. (1955). Physical and biological processes determining the distribution of zooplankton in a tidal estuary. Biol. Bull. mar. biol. Lab., Woods Hole 109: 211-225

Bartram, W. (1981). Experimental development of a model for the feeding of neritic copepods on phytoplankton. J. Plankton Res. 3: 25-52

Brooks, J. L., Dodson, S. I. (1965). Predation, body size, and composition of plankton. Science 150: 28-35

Carlson, D. J., Townsend, D. W., Hilyard, A. L., Eaton, J. F. (1984). Effect of an intertidal mudflat on plankton of the overlying water column. Can. J. Fish. Aquat. Sci. 41: $1523-1528$

Checkley, D. M. (1982). Selective feeding by Atlantic herring (Clupea harengus) larvae on zooplankton in natural assemblages. Mar. Ecol. Prog. Ser. 9: 245-253

Cushing, D. H. (1983). Are fish larvae too dilute to affect the density of their food organisms? J. Plankton Res. 5: $847-854$

Davis, C. S. (1984). Predatory control of copepod seasonal cycles on Georges Bank. Mar. Biol. 82: 31-40

Deason, E. E., Smayda, T J. (1982). Ctenophore-zooplankton- 
phytoplankton interactions in Narragansett Bay, Rhode Island, USA during 1972-1977. J. Plankton Res. 4: 203-217

Drenner, R. W. McComas, S. R. (1980). The roles of zooplankter escape ability and fish size selectivity in the selective feeding and impact of planktivorous fish. In: Kerfoot, W. C. (ed.) Evolution and ecology of zooplankton communities. Univ. Press of New England, Hanover, NH, p. 580-586

Durbin, A. G., Durbin, E. G. (1975). Grazing rates of the Atlantic menhaden Brevoortia tyrannus as a function of particle size and concentration. Mar Biol. 33: 265-277

Fancett, M. S., Kimmerer, W. J. (1985). Vertical migration of the demersal copepod Pseudodiaptomus as a means of predator avoidance. J. exp. mar. Biol. Ecol. 88: 31-43

Feigenbaum, D. F., Kelly, M. (1984). Changes in the lower Chesapeake Bay food chain in presence of the sea nettle Chrysaora quinquecirrha (Scyphomedusa). Mar. Ecol. Prog. Ser. 19: 39-47

Frank, K. T. (1986). Ecological significance of the ctenophore Pleurobrachia pileus off southwestern Nova Scotia. Can. J. Fish. Aquat. Sci. 43: 211-222

Fulton, R. S. III. (1982). Predatory feeding of two marine mysids. Mar. Biol. 72: 183-191

Fulton, R. S. III. (1983). Interactive effects of temperature and predation on an estuarine zooplankton community. J. exp. mar. Biol. Ecol. 72: 67-71

Fulton, R. S. III. (1984a). Predation, production and the organization of an estuarine copepod community. J. Plankton Res. 6: 399-415

Fulton, R. S. III. (1984b). Distribution and community structure of estuarine copepods. Estuaries 7. 38-50

Fulton, R. S. III. (1985). Predator-prey relationships in an estuarine littoral copepod community. Ecology 66: 21-29

Gerritsen, J., Strickler, J. R. (1977). Encounter probabilities and community structure in zooplankton: a mathematical model. J. Fish. Res. Bd Can. 34: 73-82

Greve, W. (1981). Invertebrate predator control in a coastal marine ecosystem: the significance of Beroe gracilis (Ctenophora). Kieler Meeresforsch. 5: 211-217

Hall, D. J., Threlkeld, S. T., Burns, C. W., Crowley, P. H. (1976). The size efficiency hypothesis and the size structure of zooplankton communities. Ann. Rev. Ecol. Syst. 7 : $177-208$

Heron, A. C. (1973). A specialized predator-prey relationship between the copepod Sapphirina angusta and the pelagic tunicate Thalia democratica. J. mar. biol. Ass. U.K. 53: $429-435$

Hobson, E. S., Chess, J. R. (1976). Trophic interactions among fishes and zooplankters nearshore at Santa Catalina Island, California. Fish. Bull. U.S. 74: 567-598

Howard, R. K., Koehn, J. D. (1985). Population dynamics and feeding ecology of pipefish (Syngnathidae) associated with eelgrass beds of Western Port, Victoria. Aust. J. mar. Freshwat. Res. 36: 361-370

Huntley, M. E., Hobson, L. (1978). Medusa predation and plankton dynamics in a temperate fjord, British Columbia. J. Fish. Res. Bd Can. 35: 257-261

Jagger, R., Kimmerer, W., Jenkins, G. (1988). Food of the cladoceran Podon intermedius in a marine embayment. Mar. Ecol. Prog. Ser. 43: 245-250

Jenkins, G., Milward, N., Hartwick, R. (1984). Food of larvae of Spanish mackerels, genus Scomberomorus (Teleostei: Scombridae), in shelf waters of the Great Barrier Reef. Aust. J. mar. Freshwat. Res. 35: 477-482

Ketchum, B. H. (1954). Relation between circulation and planktonic populations in estuaries. Ecology 35: 191-200

Kimmerer, W J., McKinnon, A. D. (1985). A comparative study of the zooplankton in two adjacent embayments,
Port Phillip and Westernport Bay, Australia. Estuar. coast. Shelf Sci. 21: 145-159

Kimmerer, W. J., McKinnon, A. D. (1987a). Growth, mortality, and secondary production of the copepod Acartia tranteri in Westernport Bay, Australia. Limnol. Oceanogr. 32 : $14-28$

Kimmerer, W. J., McKinnon, A. D. (1987b). Zooplankton in a marine bay. I. Horizontal distributions used to estimate net population growth rates. Mar. Ecol. Prog. Ser. 41. 43-52

Kimmerer, W. J., McKinnon, A. D. $(1987 \mathrm{c})$. Zooplankton in a marine bay. II. Vertical migration to maintain horizontal distributions. Mar Ecol. Prog. Ser. 41: 53-60

Kinne, O. (1967). Physiology of estuarine organisms with special reference to salinity and temperature: general aspects. In: Lauff, G. H. (ed.) Estuaries, AAAS, Washington, p. $525-540$

Kremer, P. (1979). Predation by the ctenophore Mnemiopsis leidyi in Narragansett Bay, R. I. Estuaries 2: 97-105

Landry, M. R. (1978). Population dynamics and production of a planktonic marine copepod, Acartia clausii, in a small temperate lagoon on San Juan Island, Washington. Int. Revue ges. Hydrobiol. 63: 77-119

Landry, M. R. (1983). The development of marine calanoid copepods with comment on the isochronal rule. Limnol. Oceanogr. 28: 614-624

Leong, R. J. H., O Connell, C. P. (1969). Laboratory study of particulate and filter feeding in the northern anchovy (Engraulis mordax). J. Fish. Res. Bd Can. 26: 557-582

Lonsdale, D. J. (1981). Influence of age-specific mortality on the life history traits of two estuarine copepods. Mar Ecol. Prog. Ser. 5: 333-340

Lonsdale, D. J., Heinle, D. R., Siegfried, C. (1979). Carnivorous feeding behavior of the adult calanoid copepod Acartia tonsa Dana. J. exp. mar. Biol. Ecol. 36: 235-238

Maly, E. J. (1970). The influence of predation on the adult sex ratios of copepod species. Limnol. Oceanogr. 15 (4): $566-573$

McGowan, J. A. (1974). The nature of oceanic ecosystems. In Miller, C. B. (ed.) The biology of the Oceanic Pacific. OSU Press, Corvallis, Oregon, p. 9-28

Mckinnon, A. D. (1988). The genus Acartia (Copepoda Calanoida) in Port Phillip Bay, Western Port, and the adjacent waters of Bass Strait, with particular reference to size polymorphism in Acartia tranteri Bradford. M.S. thesis, University of Melbourne

Miller, C. B. (1983). The zooplankton of estuaries. In: Ketchum, B. H. (ed.) Estuaries and enclosed seas. Elsevier, Amsterdam, p. 103-149

Miller, C. B., Johnson, J. K., Heinle, D. R. (1977). Growth rules in the marine copepod genus Acartia. Limnol. Oceanogr. 22: $326-335$

Möller, H. (1984). Reduction of a larval herring population by jellyfish predators. Science 224: 621-622

Mullin, M. M. (1979). Differential predation by the carnivorous marine copepod, Tortanus discaudatus. Limnol. Oceanogr. 24: $774-777$

Mullin, M. M., Evans, P. M. (1974). The use of a deep tank in plankton ecology. Part 2. Efficiency of a planktonic food chain. Limnol. Oceanogr. 19: 902-911

Newbury, T. K. (1972). Vibration perception by chaetognaths. Nature, Lond. 236: 459-460

O'Brien, W. J., Slade, N. A., Vinyard, G. L. (1976). Apparent size as the determinant of prey selection by bluegill sunfish (Lepomis macrochirus). Ecology 55: 1042-52

Paffenhöfer, G.-A., Stearns, D. E. (1988). Why is Acartia tonsa (Copepoda: Calanoida) restricted to nearshore environments? Mar. Ecol. Prog. Ser. 42: 33-38 
Peterson, W. T., Ausubel, S. J. (1984). Diet and selective feeding by larvae of Atlantic mackerel Scomber scombrus on zooplankton. Mar Ecol. Prog. Ser 17: 65-75

Petipa, T., Pavlova, E., Midonov, G. (1970). The food web structure, utilization, and transport of energy by trophic levels in the planktonic communities. In: Steele, J. H. (ed.) Marine food chains. Oliver and Boyd, Edinburgh, p. 142-187

Purcell, J. E. (1981). Feeding ecology of Rhizopshysa eysenhardti, a siphonophore predator of fish larvae. Limnol. Oceanogr. 26: 424-432

Rassoulzadegan, F., Sheldon, R. W. (1986). Predator-prey interactions of nanozooplankton and bacteria in an oligotrophic marine environment. Limnol. Oceanogr 31: $1010-1021$

Reeve, M. R. (1966). Observations on the biology of a chaetognath. In: Barnes, H. (ed.) Some contemporary studies in marine science. Allen and Unwin, London, p. 613-630

Reeve, M. R., Baker, L. D. (1975). Production of two planktonic carnivores (chaetognath and ctenophore) in south Florida inshore waters. Fish. Bull. U.S. 73: 238-248

Reeve, M. R., Walter, M. A. (1976). A large-scale experiment on the growth and predation potential of ctenophore populations. In: Mackie, G. O. (ed.) Coelenterate ecology and behavior. Plenum, New York, p. 187-199

Reeve, M. R., Walter, M. A. (1978). Nutritional ecology of ctenophores - a review of recent research. Adv. mar Biol. 15: $249-287$

Riley, G. W. (1967). The phytoplankton of estuaries. In: Lauff G. H. (ed.) Estuaries. AAAS, Washington, p. 316-326

Rippingale, R. J., Hodgkin, E. P. (1974). Predation effects on the distribution of a copepod. Aust. J. mar Freshwat. Res. 26: $81-91$

This article was submitted to the editor
Robertson, A. I. (1980). The structure and organization of an eelgrass fish fauna. Oecologia (Berl.) 47: 76-82

Robertson, A. I., Howard, R. K. (1978). Diel trophic interactions between vertically-migrating zooplankton and their fish predators in an eelgrass community. Mar. Biol. 48: 207-213

Rogers, H. (1940). Occurrence and retention of plankton within an estuary. J. Fish. Res. Bd Can. 5: 164-171

Ryther, J. H., Sanders, J. G. (1980). Experimental evidence of zooplankton control of the species composition and size distribution of marine phytoplankton. Mar. Ecol. Prog. Ser. 3: $279-283$

Singarajah, K. (1969). Escape reactions of zooplankton: the avoidance of a pursuing siphon tube. J. exp. mar. Biol. Ecol. 3171-178

Stoecker, D., Egloff, D. (1987). Predation by Acartia tonsa Dana on planktonic ciliates and rotifers. J. exp. mar. Biol. Ecol. 110: 53-68

Strickland, J. D. H., Parsons, T. R. (1972). A practical handbook of seawater analysis. Bull. Fish. Res. Bd Can. 167

Sullivan, B. K. (1980). In situ feeding behavior of Sagitta elegans and Eukhronia hamata (Chaetognatha) in relation to the vertical distribution and abundance of prey at Ocean Station P'. Limnol. Oceanogr. 25: 317-326

Vuorinen, I., Rajasilta, M., Salo, J. (1983). Selective predation and habitat shift in a copepod species - support for the predation hypothesis. Oecologia (Berl.) 59: 62-64

Warren, G. J., Evans, M. S., Jude, D. J., Ayers, J. C. (1986). Seasonal variations in copepod size: effects of temperature, food abundance, and vertebrate predation. J. Plankton Res. 8: 841-854

Zaret, T M., Kerfoot, W. C. (1975). Fish predation on Bosminia longirostris: body-size selection versus visibility selection. Ecology 56 (1): 232-237

Manuscript first received: May 27, 1988

Revised version accepted: January 24, 1989 